\title{
Bringing Back Main Street in Morrisburg
}

Rob Hunter Ec.D. (F)

The suggestion that the Municipality of South Dundas should look at developing and implementing a Main Street Morrisburg Streetscape Project was highlighted in a recently completed report. The report was conducted under the Ontario Ministry of Agriculture, Food and Rural Affairs' First Impressions Community Exchange (FICE) program. The FICE report in question was provided to the Municipality of South Dundas by representatives from the Town of Gananoque in September 2016 and this project was one of the major recommended action items that was contained within it (Zandbergen, 2016).

For more than half a century, the Village of Morrisburg has lacked a proper Main Street Business District. It all started back in the mid-1950's when about a third of the Village of Morrisburg, including the Main Street area, which was the original business district was lost forever under a wall of water. This was caused by the flooding required to construct the St. Lawrence Seaway due to the need to deepen the seaway to allow larger ships to navigate the river. In the process, Lake St. Lawrence was created. Because the flooding included significant parts of Morrisburg (including the central business district) along with other entire villages like Farran's Point and Aultsville in Eastern Ontario, Morrisburg is included in some publications as what has become known as the Lost Villages.

Keywords: Streetscape, First Impressions Program, Main Street, Business District, Lost Villages

\section{Introduction}

The suggestion that the Municipality of South Dundas should look at developing and implementing a Main Street Morrisburg Streetscape Project was highlighted in a recently completed report. The report was conducted under the Ontario Ministry of Agriculture, Food and Rural Affairs' First Impressions Community Exchange (FICE) program. The FICE report in question was provided to the Municipality of South Dundas by representatives from the Town of Gananoque in September 2016 and this project was one of the major recommended action items that was contained within it (Zandbergen, 2016).

\section{Background}

For more than half a century, the Village of Morrisburg has lacked a proper Main Street Business District. It all started back in the mid-1950's when about a third of the Village of Morrisburg, including the Main Street area, which was the original business district was lost forever under a wall of water (Morrisburg, ghosttownpix.com, n.d.). This was caused by the flooding required to construct the St. Lawrence Seaway due to the need to deepen the seaway to allow larger ships to 
navigate the river. In the process, Lake St. Lawrence was created. Because the flooding included significant parts of Morrisburg (including the central business district) along with other entire villages like Farran's Point and Aultsville in Eastern Ontario, Morrisburg is included in some publications as what has become known as the Lost Villages.

Figure 1. Extent of the Flooding of Morrisburg.

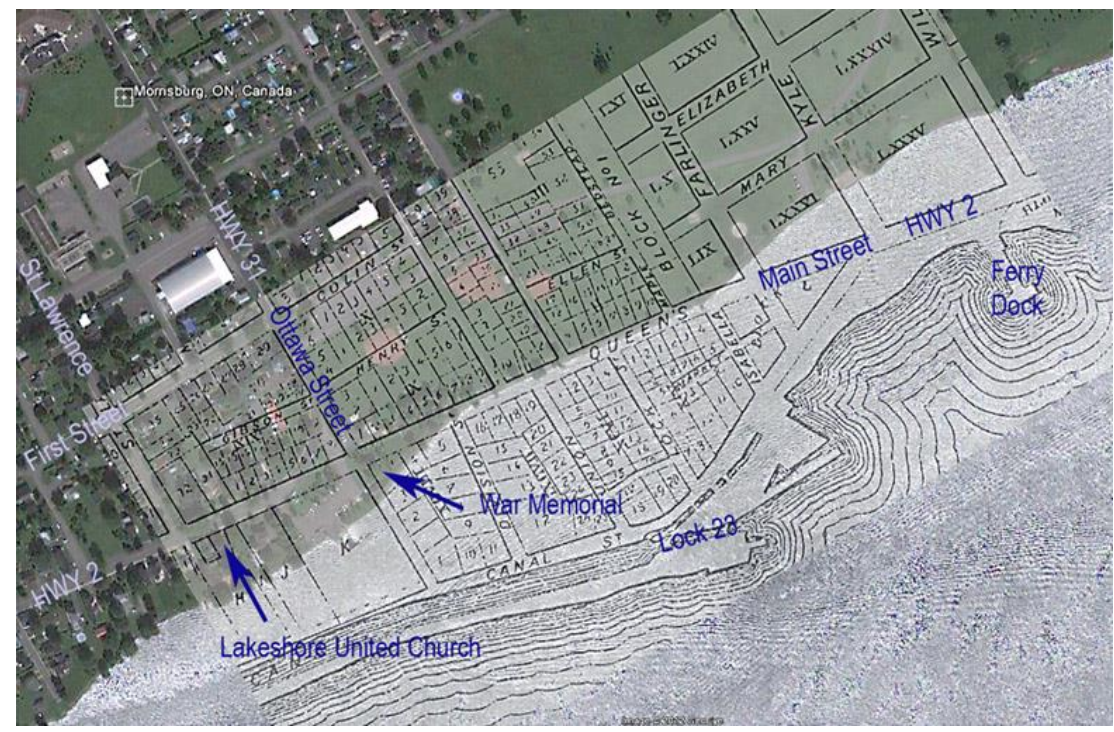

Source: Municipality of South Dundas Photo Bank

Figure 2. Original Main Street Morrisburg 1950's

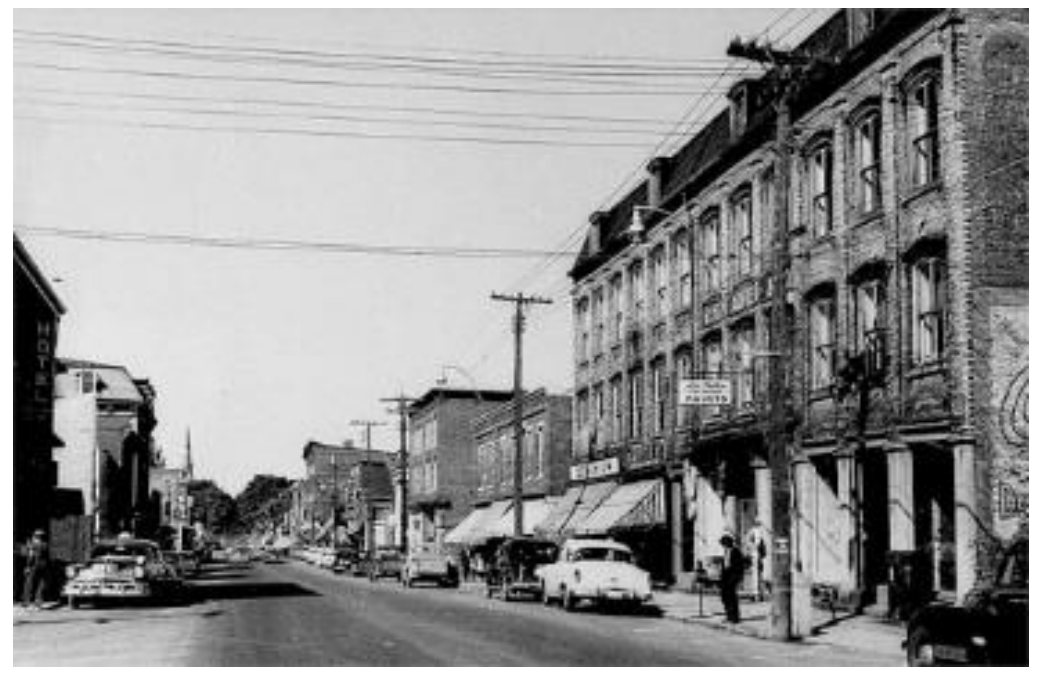

Source: Municipality of South Dundas Photo Bank 


\section{Figure 3. Aerial View of Downtown Morrisburg Post Flooding}

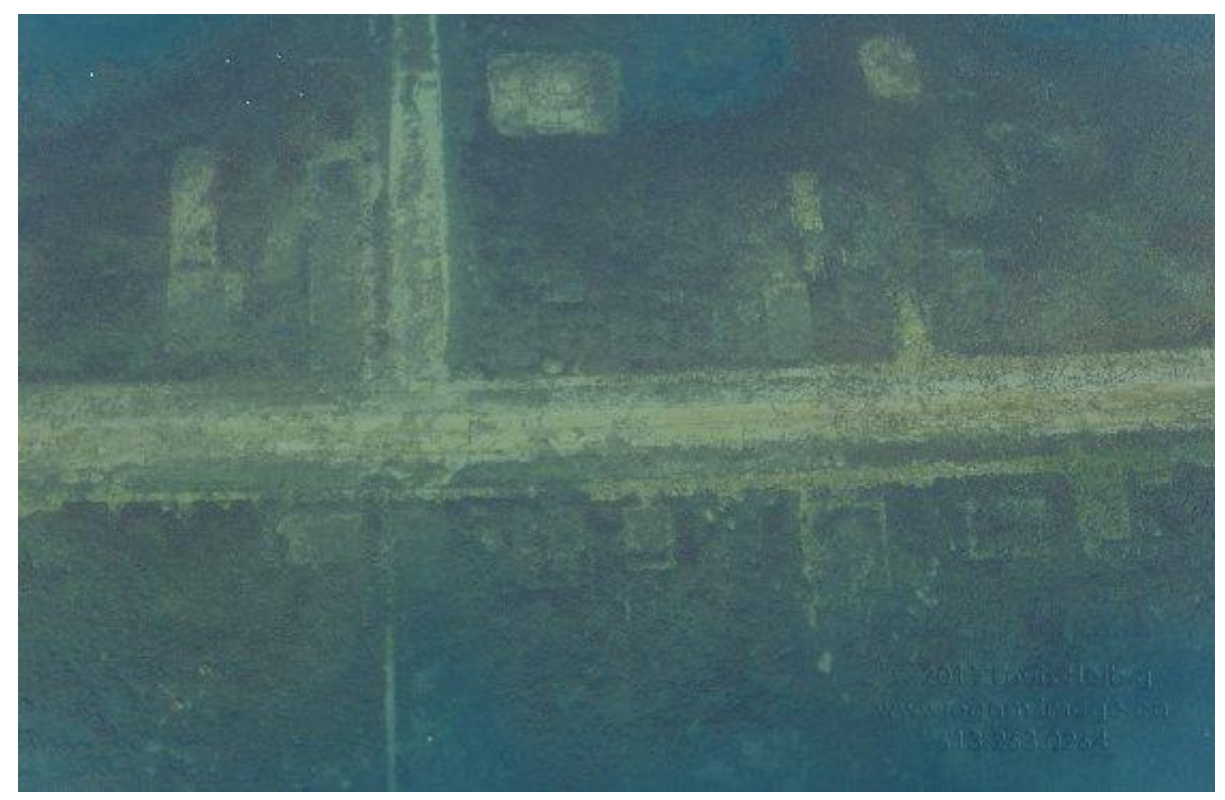

Source: Municipality of South Dundas Photo Bank

To make up for the loss of the downtown, a new commercial highway (the Kings Highway 2) and commercial plaza were built. However, the damage was done as the heart of the community was lost and has been lost for more than 60 years now.

It cannot be stated how much of a loss this was for the Village of Morrisburg. The central business district and numerous heritage and cultural properties where lost. In effect, the heart of the community was ripped out of Morrisburg. The Morrisburg Plaza, while it is a significant asset, still lacks the aesthetic look and feel and the walkable linkages to a Main Street; it also lacks the modern enhancements that shoppers and tourists expect (Zandbergen, 2016).

\section{Downtown Revitalization}

It is important to note that the Province takes downtown revitalization very seriously. In fact, the Ontario Ministry of Agriculture, Food and Rural has a Downtown Revitalization program that is offered to communities around the province. The basic concepts and part of a revitalization program are described below.

When it comes to revitalizing a downtown, people often think of structural and tangible improvements; however, frequently there is more to the picture than the appearance of the downtown. Each downtown has its own unique architecture, cultural traditions, heritage and other assets to build on. A successful downtown revitalization project focuses not only on a community's buildings and structures but on many factors including: the demography of the area, 
overall attractiveness to investors, and the impression a community gives visitors. The "fourpoint approach" to downtown revitalization includes:

- Economic Development - Assists merchants in targeting new customer/market segments and identifies new business opportunities that could complement the downtown mix.

- Leadership and Management - Engages all downtown stakeholders in the enhancement and improvement of all aspects of the downtown's operation by ensuring the coordination of efforts and that the implementation of the strategy developed is managed to maximize the downtown's revitalization opportunities.

- Marketing and Promotion - Ensures that the identity and positive image of the downtown is communicated and that activities enhance the downtown.

- Physical Improvements - Restores facades, streetscaping, parking, safe and walkable communities (Downtown Revitalization, n.d.).

This paper will focus on the 'fourth pillar' of Downtown Revitalization which is the 'Physical Improvements' part of the revitalization efforts.

\section{Streetscape and Streetscaping}

Streetscape refers to urban roadway and conditions as they impact street users and nearby residents. Streetscaping recognizes that streets are places where people engage in various activities, including but not limited to motor vehicle travel. Streetscapes are an important component of the public realm (public spaces where people interact), which helps define a community's aesthetic quality, identity, economic activity, health, social cohesion and opportunity, not just its mobility. Streetscaping (programs to improve streetscape conditions) can include changes to the road cross sections, traffic management, sidewalk conditions, landscaping (particularly tree cover), street furniture (lighting poles, benches, garbage cans, etc.), building fronts and improving signage (Muhlhausen, 2005).

By creating more attractive street environments, Streetscaping can support Economic Development, including increased retail activity, property development, land values and tax revenues (Fleming, Turner \& Tarjomi, 2013).

\section{Why Now?}

Now is the time to make things right and re-establish a 'Main Street' in the Village of Morrisburg and provide the community with a Main Street that will enhance economic development and tourism in the community. It should be noted that in 1987, there was a study done that suggested some landscaping elements and realignment of the parking within the Morrisburg Plaza property and also some significant upgrades to the Plaza itself. Unfortunately, there is no indication why the project did not proceed back then as this project was before the 
Municipality of South Dundas was created by amalgamation in 1998 and the history as to why it didn't move forward was lost.

\section{Figure 4. Morrisburg Plaza Streetscape Plan}

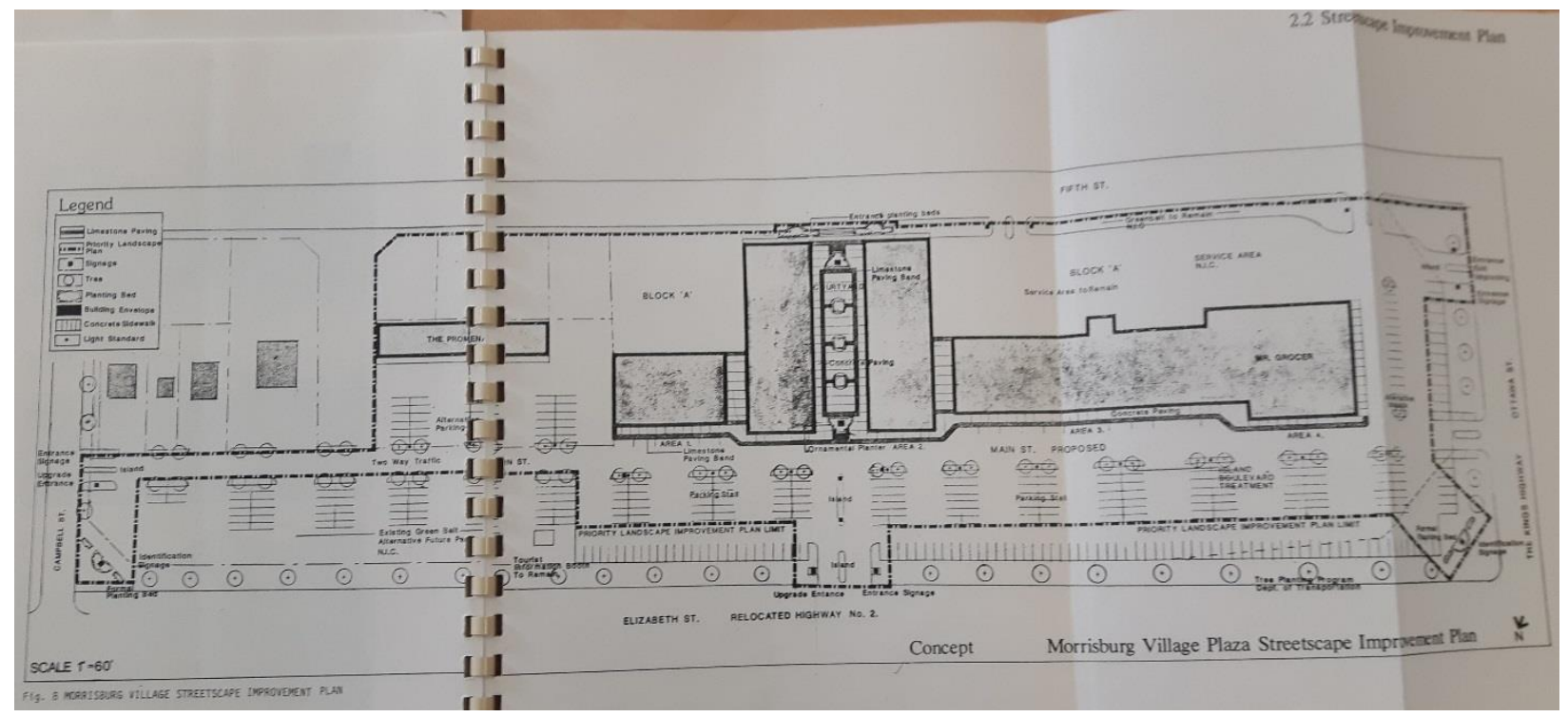

Source: Morrisburg Plaza Streetscape Improvement Plan. (1987)

Over the past short while a few community members, business people and municipal staff have discussed the need to establish an integrated network of sidewalks and path walks to help mitigate the conflicts between vehicle traffic and pedestrians. At the same time of these discussions, the recommendation of the introduction of the 'Main Street Concept' was highlighted as a recommendation in the First Impressions Community Exchange Report that was completed by representatives from our partner community the Town of Gananoque (FICE Report).

It is believed that at this moment in time it would be best to focus both on the operational aspect of the project, along with the urban design elements that could be incorporated and would create the concept for 'Main Street Morrisburg'. The objective would be to tie the functionality of the movement of pedestrians along with enhanced streetscape elements, which would include surface treatments, boulevards, vegetation, decorative poles/lighting and other elements that would create Main Street Morrisburg.

It will also be worth consideration in a later phase to look at incorporating some sort of corridor enhancements between the Main Street that would be created as part of the project and the waterfront, to further tourism development in the Village. 


\section{Importance of Tourism}

It should be noted that Tourism in Ontario is a $\$ 22.1$ billion dollar industry, which is very significant and ranks $7^{\text {th }}$ among Ontario's export industries. (Sobora 2009). It should also be noted that the Ontario Government sees Tourism as an important sector and hired consulting firm to develop a Tourism Investment Strategy and Implement Plan in 2011 (Millier, Dickinson, Blais).

In the local context, it was clear in the First Impressions Community Exchange report by the Town of Gananoque that the visitation team saw the importance of tourism to the community. They suggested that existing tourism assets along with streetscape beautification project, should it be implemented could really enhance the tourism sector in Morrisburg by having a beautiful Main Street (Zandbergen, 2016).

It should be noted that Morrisburg is home to a beautiful waterfront that is owned in large part by the Municipality and it has several amenities like a boat launch ramp, public beach, amphitheatre, and waterfront trail. These assets are augmented by other tourism assets in the municipality like the Iroquois Seaway Locks, Upper Canada Village and the original McIntosh Farm in Dundela, Ontario, which is the birthplace of the McIntosh Apple, all of which help bring tourists to the area.

\section{Proposed Project Area}

The proposed project area would be a significant portion of County Rd 2 that runs through Morrisburg and would extend from the Upper Canada Playhouse in the west to the McIntosh Inn' in the east. Given this area also includes a major intersection, it would also include a small portion of Ottawa Street (also known as County Rd 31/Bank Street) from Felker Way in the north to Fifth Street in the south. 
Figure 5. Proposed Morrisburg Main Street Project Area

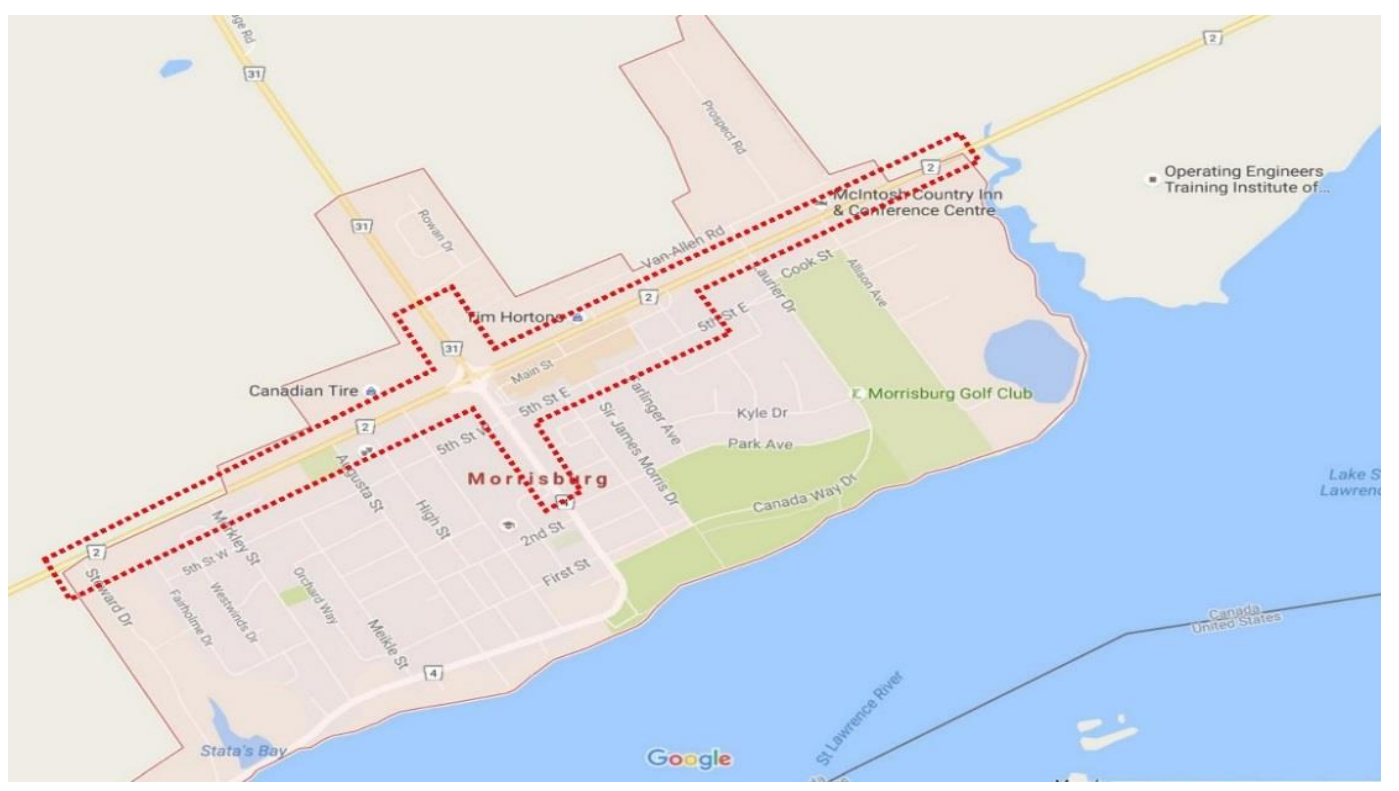

Source: Hunter, R. (2017). https://www.google.ca/maps.

\section{Current Situation - What currently exists}

As can be seen from the photo below, County Rd 2 through the Village of Morrisburg has the appearance of a highway commercial district. It is not very aesthetically pleasing and it lacks any urban design streetscape elements. There is one traffic light at the corner of County $\mathrm{Rd} 2$ and Ottawa Street (also known as County Rd 31/Bank Street).

\section{Figure 6. County Rd 2 in Morrisburg}

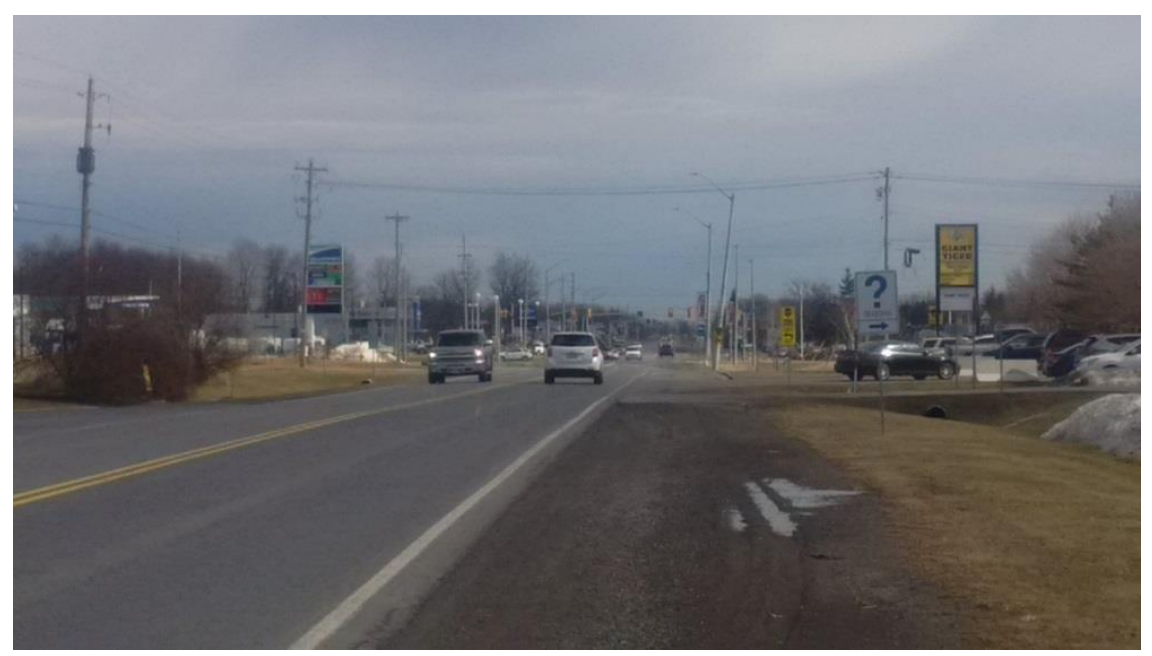

Source: Hunter, R. (2016). https://www.google.ca/maps. 
On the north side of the road are some significant major retail/service chains such as Canadian Tire, McDonalds, Tim Hortons, and Home Hardware. On the south side of the road you will find the Morrisburg Plaza that consists of approximately 50 retail/service outlets including a grocery store, numerous restaurants, pharmacy, two banks, Beer store and LCBO outlet.

Figure 7. Morrisburg Plaza on south side of County Rd 2

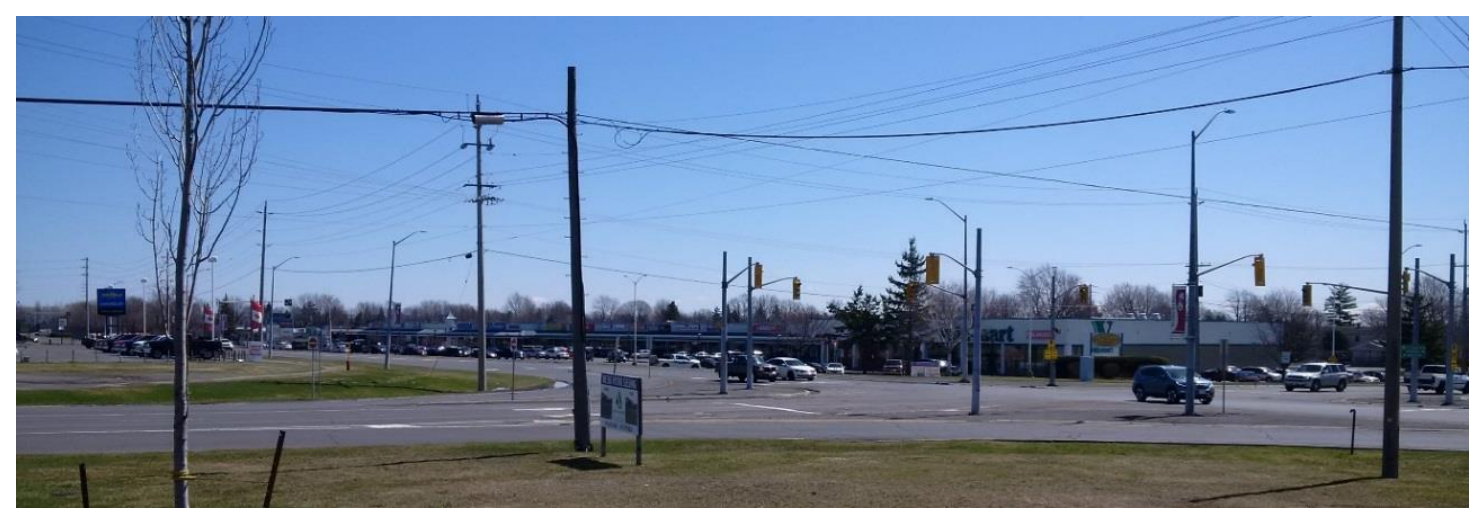

Source: Hunter, R. (2016). https://www.google.ca/maps.

\section{SWOT Analysis}

To help move the process forward an initial SWOT Analysis was developed based on feedback from discussions held with a number of stakeholders over the last short while. Stakeholders included certain Municipal Staff members, representatives from the Chamber of Commerce, the Business Improvement Area, some local residents and also some commentary that was included in the FICE Report. The initial SWOT results are listed below:

\section{Strengths}

- Local tourism assets

- Active retail centre on County Rd 2 (both north and south side)

- Retail outlets act as 'rural shopping hub' in close proximity to Hwy 401

- Possible connections with the waterfront

- Strong residential presence on the periphery of the business district

\section{Weaknesses}

- Pedestrian vs vehicle conflict

- Lack of defined greenery / landscape elements / aesthetics

- Lack of sidewalks and pathways for pedestrians

- Car-centric retail outlets

- Lack of sense of destination for both residents and tourists 


\section{Opportunities}

- Landscaping

- Create pedestrian friendly infrastructure i.e. sidewalks / pathways

- Create something visually unique

- Create a sense of arrival

- Possible stand-alone Tourism Visitor Centre / Kiosk

- Possible waterfront corridor enhancement as a future phase to connect the central business district to the waterfront

- Grants / Funding available from various sources/programs

\section{Threats}

- Regulations

- Traffic speeds / pedestrian safety

- Costs (need to look at phased implementation) / Council

- Conflicts between rural and urban vision

- Jurisdictional issues / Other levels of Government

\section{What is hoping to be achieved}

In short, what is hoping to be achieved is to have a strong Main Street in the Village of Morrisburg. One that marries the functional aspects along with urban streetscape design elements and aesthetics. This project could very well act as an important tool that would help with business recruitment. A community that looks good and has a good sense of place is something that businesses take into account while determining where to locate. It would also give the community a sense of pride and provide a different and distinctive look that would differentiate it from other communities that are found on the $80 \mathrm{~km}$ stretch of County $\mathrm{Rd} 2$ from the Town of Prescott to the City of Cornwall. The introduction of items such as new pavement, streetlights, banners and boulevards would 'unify the street'.

\section{Morrisburg Plaza}

The other element of streetscaping comes with the appearance of the retail/commercial buildings along the street.

Pedestrianized commercial districts (including malls and plazas) can support urban revitalization and economic development by creating a lively and friendly environment that attracts residents and visitors (Rodriguez, 2010; Tolley, 2011).

Given this, the other important physical component of the proposed Main Street Morrisburg project would be to develop a conceptual beautification and revitalization plan for the Morrisburg Plaza. The parking lot, sidewalks and the canopy of the plaza are owned by the 
Municipality of South Dundas, while the facades and buildings are owned by various individuals and businesses. It should be noted that the Plaza is part of an established 'Business Improvement Area' under Section 204 of the Ontario Municipal Act and operates under the name of 'Downtown Morrisburg,'

Noted in the First Impressions Community Exchange report by the Town of Gananoque Representatives, was that they were very surprised to find no traditional downtown in the Village of Morrisburg, but instead, a County Road with major retail outlets and a dated plaza. The plaza was identified as an asset that really could use some physical improvements that would help make it a tourism and retail destination (Zandbergen, 2016).

It is envisioned that it will be important to work with the BIA and the individual property owners to development concepts for the Morrisburg Plaza as a separate phase of the project as it moves forward. Also it will be important to address the facades and landscaping elements of the businesses located on the northern part of County Road 2.

\section{Community Improvement Plan}

One of the instruments that has been identified that could assist the revitalization of the Plaza and other properties located in the project area is the ability of the Municipality to develop and implement a Community Improvement Plan (CIP). A municipality is allowed to provide funding under section 28 of the Ontario Planning Act to building owners to improvement their properties through a CIP. This is an important program as generally Municipalities are not allowed to provide funding or bonusing to private commercial interests as noted in section 106 of the Municipal Act.

One of South Dundas' neighbouring municipalities developed and implemented a CIP four years ago. Since the inception of the Township of North Dundas CIP, the program has seen twentythree (23) properties receive funding support and revitalized through the program. In total the program has seen the capital outlay by the building owners reach over $\$ 800,000$. This shows that a CIP can be effective in a small community (North Dundas CIP).

\section{Proposed Project Partners}

In order to successfully bring about a project of this importance in size and scope, it will only be possible to do so by engaging several partners. This section will identify and list the proposed project partners that could help contribute and bring this project from concept to reality over the next few years. 


\section{Municipality of South Dundas (Lower Tier Government)}

The Municipality of South Dundas would take the overall responsibility for development, implementing and leading the project. The key municipal staff members that will be involved in the project would be the C.A.O./Treasurer, Director of Public Works, Director of Planning \& Enforcement and the Economic Development Officer.

\section{United Counties of Stormont, Dundas and Glengarry (Upper Tier Government)}

County Rd 2 which is the primary focus of this project, is owned and maintained by the United Counties of Stormont, Dundas and Glengarry (SDG Counties). Given this, it is evident that the Director of Transportation from SDG Counties will be a very important person to engage as part of the project.

A meeting with Ben deHaan, SDG Counties Director of Transportation took place in the past short while to provide him with the context and background on what is hoping to be achieved. While the discussion was of an initial nature, it did bear fruit as he was open to the concept, if it was indeed to move forward.

It was important to establish if the SDG Counties would be supportive 'in-principle' of the project and to discuss the County infrastructure. As it turned out, the meeting was very timely as the road surface of County Rd 2 in Morrisburg currently falls within the five-year window for full replacement. Given this, SDG Counties budget would cover the costs such as road surface, paved shoulder and boulevards etc. All of this will depend on what type of concepts could be developed as the project moves forward.

It was certainly beneficial to have this meeting and it will be important to ensure that Mr. deHaan be included in future meetings as work takes place toward the development of the project concept and to present the concept to South Dundas Municipal Council.

\section{Business Improvement Association}

The Business Improvement Association (BIA) represents all the business owners and landlords in the Morrisburg Plaza and some associate members that are located on the north side of County Rd 2 across from the plaza.

It will be important to engage the BIA in the project as it moves forward to ensure that the feedback from the membership in relation to the streetscape concept is captured. It will also be important to discuss the revitalization of the Plaza façade, the development of a community improvement plan and potential upgrades to the parking lot, sidewalks and the canopy. 
The other area that will require discussion after the concept is developed and costed is any possible funding support from the BIA toward the project. There are several different mechanisms available for funding, including the introduction of a special project levy.

\section{South Dundas Chamber of Commerce}

To ensure all businesses located in the project study area are included in the process, the Chamber of Commerce will be asked to provide input into the project.

\section{Business and Property Owners that are non-Chamber and BIA members}

There are a few businesses and property owners that are not Chamber or BIA members that fall within the project area that will need to be involved as part of the plan moving forward.

\section{South Dundas Ratepayers}

Considering this is an important Community Development project, South Dundas ratepayers would also need to be engaged as part of the process moving forward. Prior to development of the concepts for the streetscape and the parking lot/plaza, they will be asked to participate in a survey that will allow them to share ideas as to what they think should be included as part of the project.

While not every idea can or will be included in the final draft concepts that will be presented via public meetings, it is felt that engaging the community early in the process will help mitigate concerns and would assist with the public 'buying in' to the project.

\section{Ontario Ministry of Agriculture, Food and Rural Affairs}

Given that the project focuses on one of the four core principles of the OMAFRA Downtown Revitalization Program, the potential for OMAFRA staff to assist in an 'in-kind' capacity exists to help refine the project as it moves forward.

\section{SD \& G Community Futures Development Corporation}

The Cornwall and the Counties Community Futures Development Corporation (CFDC) is a private, non-profit development agency. The organization engages with the communities throughout the Counties of SDG and assists in numerous ways with providing funding support.

The CFDC happens to have a program that is a companion program to municipal CIP programs and extends low-interest loan options to businesses and property owners looking to take advantage of a CIP program. This is something that can be highlighted to the business/property owners in the project area as something that would be available to assist them with their plans. 


\section{Morrisburg Waterfront Committee}

Given the suggestion that not only should County Rd 2 be part of the project area, but also a part of County Rd 31 (Bank St / Ottawa St) in the FICE report, it is suggested to reach out to the Morrisburg Waterfront Committee as the project moves forward. This is a Committee of Council that is charged with providing input on how to develop the waterfront and any enhancements to the corridor on County Rd 31/Bank St to the waterfront. This will help to share ideas and possibly coordinate the waterfront corridor enhancements as the project moves forward.

\section{Recommendations}

Based on the research conducted the following section details some of the recommended steps to advancing the proposed project of creating Main Street Morrisburg over the next five years in keeping with the SDG Counties timeframe for rejuvenation of County Rd 2 in Morrisburg.

1) Based on the research conducted, put together a presentation that includes a copy of this paper and a recommendation to the Council of the Municipality of South Dundas to support 'in principle' the Main Street Morrisburg project.

2) Establish a working group of municipal staff and a number of stakeholders to further refine and develop the Main Street Morrisburg project.

3) Hire a consulting firm to work with the working group to review the research to date, conduct further research, marry the proposed ideas with GIS mapping so as to determine the workable project area and draft the streetscape concepts.

4) Engage the public by introducing a survey to ask them for their ideas and suggestions as it relates to Main Street Morrisburg.

5) Have discussions with Morrisburg Waterfront Committee on how they may wish to coordinate their efforts and those of the Main Street Morrisburg working group.

6) Work with the BIA to determine ideas and suggestions for the Morrisburg Plaza and the parking lot area.

7) Municipality and BIA to jointly hire (if agreeable) an architectural firm to develop some draft concepts of for revitalizing the Morrisburg Plaza.

8) The Director of Planning \& Enforcement and the Economic Development Officer to work jointly to develop a draft Community Improvement Plan. 
9) Hold public meetings to present draft concepts for Main Street Morrisburg and draft Community Improvement Plan.

10) Work with the Counties and Engineering firms to detail the costing of the project.

11) Apply for and secure funding for the project and proceed with Engineering for the project.

12) Implement Main Street Morrisburg Project for the Streetscape and the Plaza.

13) Work with the BIA and partners to look at addressing the other three (3) pillars of Downtown Revitalization as things to move forward.

14) Expanding on point number 13 above, the municipality should also look at developing some sort of residents' attraction marketing materials and program that could be provided to tourists, in the hopes that they would one day look at settling in the community. Something along the line of 'Come for the day and stay for a lifetime' themed campaign. This would be developed after the revitalization effort takes place.

\section{Conclusion}

Based on the research conducted to date and the preliminary discussions held with various stakeholders including members of South Dundas Council the proposed Main Street Morrisburg project is worthy of consideration.

A concerted effort should be taken by the Municipality of South Dundas to further advance the development and implementation of the Main Street Morrisburg project.

\section{Author biography}

Rob is a graduate of the University of Waterloo's Economic Development Program and is currently the Economic Development Officer for the Municipality of South Dundas. Prior to his employment with South Dundas, Rob spent five years as the Economic Development Officer with the Township of North Dundas. In the past he has also served as the Executive Director of the Ontario Business Improvement Area Association (OBIAA) for two years and also spent seven years as the Executive Director of the Downtown Brockville Business Improvement Area (BIA). In 2014, Rob was recognized as the Ontario East Economic Development Commission 'Economic Developer of the Year,' as voted on by his peers and he holds the Economic Development Association of Canada 'Certified Economic Developer with Fellowship' Ec.D. (F). 
He has served as a board member of the Ontario East Economic Development Commission for the last four years.

\section{References}

Downtown Revitalization. (n.d.). Ontario Ministry of Agriculture, Food and Rural Affairs. Retrieved from http://www.omafra.gov.on.ca/english/rural/edr/dr/index.html

Fleming, T., Turner, S., \& Tarjomi, L. (2013), Reallocation of Road Space, Research Report 530, NZ Transport Agency (www.nzta.govt.nz). Retrieved from www.nzta.govt.nz/resources/research/reports/530/docs/RR-530-Reallocation-of-roadspace.pdf

Millier, Dickinson, Blais, (2011) Ontario's Tourism Investment Strategy and Implementation Plan. Retrieved from http://www.mtc.gov.on.ca/en/publications/Investment_strategy.pdf

Morrisburg. (n.d.) Ghostownpix.com. Retrieved from http://www.ghosttownpix.com/lostvillages/morrisbu.html

Muhlhausen, J. (2005), Wayfinding Is Not Signage: Signage plays an important part of wayfinding -- but there's more. Signs of the Times. Retrieved from www.wayfindingdmcdesigns.ca/assets/wayfinding-is-not-signage.pdf

North Dundas. (2013). Community Improvement Plan. Retrieved from http://northdundas.com/wp-content/uploads/2012/11/Community-Improvement-PlanMay-10-2016-Final1.pdf

OMAFRA RED Program, Retrieved from http://www.omafra.gov.on.ca/english/rural/red/redrecipients 14. htm

Ontario Ministry of Municipal Affairs. (2001). Municipal Act (S.O. 2001) Retrieved from https://www.ontario.ca/laws/statute/01m25.

Rodriguez, L. (2011), Pedestrian-Only Shopping Streets Make Communities More Livable. Plantizen. Retrieved from https://www.planetizen.com/node/47517.

Sobora, G. (2009), Discovery Ontario A Report on the Future of Tourism. Retrieved from http://www.mtc.gov.on.ca/en/publications/Discover_Ontario_en.pdf

Tolley, R. (2011). Good for Busine\$: The Benefits of Making Streets More Walking and Cycling Friendly. Heart Foundation South Australia. Retrieved from https://heartfoundation.org.au/images/uploads/publications/Good-for-business.pdf.

Zandbergen, N. (2016, September 16). Iroquois Lock top gem in South Dundas, says visiting contingent. Nation Valley News. Retrieved from http://www.nationvalleynews.com/2016/09/16/iroquois-lock-top-gem-in-south-dundassays-visiting-contingent/ 
Personal communications with local stakeholders listed that were interviewed during the late fall of 2016

Shannon Geraghty - CAO/Treasurer, Municipality of South Dundas

Chris Bazinet - Director of Public Works, Municipality of South Dundas

Don Lewis - Director of Planning \& Enforcement, Municipality of South Dundas

Evonne Delegarde, Mayor, Municipality of South Dundas

Marc St. Pierre, Councillor, Municipality of South Dundas

Bill Ewing, Councillor, Municipality of South Dundas

Donnie Bowes, Vice President, South Dundas Chamber of Commerce

Geri Fitzsimmons, Executive Director, South Dundas Chamber of Commerce

Adeana McQuaig-Bedard, Executive Director, Downtown Morrisburg BIA

Sam Laurin, Board Member, Downtown Morrisburg BIA

Michael Burton, Tourism Operator, Morrisburg, Ontario

Lesley Lang, Executive Director, Cornwall and the Counties CFDC

Bruce Moore, Team Lead, Ontario Ministry of Agriculture, Food and Rural Affairs

Ben deHaan, Director of Transportation and Planning - United Counties of Stormont, Dundas and Glengarry 